\title{
ANALISIS PERBANDINGAN KINERJA KEUANGAN BANK UMUM SYARIAH HASIL SPIN OFF DAN NON SPIN OFF PERIODE 2013-20151
}

Saraya Izazi Syarafina Hisyam

Program Studi S1 Ekonomi Islam-Fakultas Ekonomi dan Bisnis-Universitas Airlangga Email: aya11594@yahoo.com

Dina Fitrisia Septiarini

Departemen Ekonomi Syariah-Fakultas Ekonomi dan Bisnis-Universitas Airlangga Email: dina.fitrisia@gmail.com

\begin{abstract}
:
The aim of the study was to determine the difference in financial performance of Islamic banks results of acquisition and spin-offs around period year of 2013-2015. Financial performance measurement of Islamic banks used capital, asset quality, earning, and liquidity factor. Thus, study used quantitative research. The Islamic bank that are used as a sample in this study including one Islamic bank result of spin off and six Islamic bank result of acquisition. The financial performances analyzed using independent sample t-test and Mann-Whitney test. The variables used in financial performance assessment are CAR, NPF, ROA, BOPO and $F D R$. The data used for this study are secondary data gathered from per semester financial report in period of June $30^{\text {th }} 2013$ to June $30^{\text {th }}$ 2015. The comparative analysis result in ratio of CAR, NPF, ROA, BOPO and FDR showed no differences in financial performance of Islamic banks result of acquisition and spin-off.
\end{abstract}

\section{Keywords: Comparative Analysis, Financial Performance, Spin Off, Acquisition}

\section{PENDAHULUAN}

\section{Latar Belakang}

Perkembangan bank umum syariah selalu didorong oleh pemerintah Indonesia. Dalam langkah perkembangan selanjutnya, diharapkan semakin banyak bank umum syariah yang berdiri di Indonesia. Sebagai langkah awal, pemerintah memperbolehkan bank umum konvensional untuk membuka unit usaha berdasarkan prinsip syariah.

Terdapat berbagai upaya yang telah dilakukan dalam rangka penguatan struktur perbankan nasional termasuk pada bank umum syariah. Upaya yang dilakukan adalah adanya Peraturan Bank Indonesia No.11/3/2009 dan 11/10/2009. Pada tahun 2005, ditetapkan persyaratan modal disetor minimum Rp 1 triliun untuk pendirian bank umum syariah yang tertuang dalam Peraturan Bank Indonesia Nomor 11/3/PBI/2009 tentang bank umum syariah pada pasal 5. Sedangkan pada tahun 2006, ditetapkan persyaratan modal disetor minimum sebesar Rp 500 miliar bagi bank umum syariah yang berasal dari spin-off unit usaha syariah yang tertuang dalam Peraturan Bank Indonesia Nomor 11/10/PBI/2009 tentang unit usaha syariah pada pasal 45 ayat 2 .

Pemilihan periode 2013-2015 didasarkan pada adanya fenomena terkait pelemahan nilai tukar rupiah dan tingginya inflasi pada periode 2013 yang menyebabkan penurunan performa kinerja keuangan bank umum syariah

dalam menghasilkan laba. Serta diakhiri pada tahun 2015 bertujuan untuk mendapatkan hasil penelitian dengan menggunakan periode terkini. pada tanggal 11 Februari 2016 
Hisyam, et al/Jurnal Ekonomi Syariah Teori dan Terapan Vol. 3 No. 11 November 2016: 872-886; ANALISIS PERBANDINGAN KINERJA KEUANGAN BANK UMUM SYARIAH HASIL SPIN OFF DAN NON SPIN OFF PERIODE 2013-2015

Pembentukan bank umum syariah dapat dilakukan dengan berbagai cara salah satunya adalah dengan cara spin off dan akuisisi. Hingga saat ini, bank umum syariah hasil spin off yang telah beroperasi adalah Bank BNI Syariah, B.P.D Jawa Barat Banten Syariah dan Bank Tabungan Pensiunan Nasional Syariah. Sedangkan untuk bank umum syariah hasil akuisisi yang telah beroperasi adalah Bank Victoria Syariah, Bank BRI Syariah, Bank Syariah Mandiri, Bank Syariah Mega Indonesia, Bank Panin Syariah, Bank Syariah Bukopin dan Bank BCA Syariah.

Penilaian kinerja bank syariah merupakan kepentingan semua pihak, yaitu: pemilik, pengelola bank dan masyarakat pengguna jasa bank.

Menurut Muhammad (2005:167),
sehubungan dengan itu Bank
Indonesia selaku Pembina dan Otoritas
Jasa Keuangan selaku pengawas
perbankan menetapkan tata cara
penilaian kinerja bank umum syariah
mengacu kepada ketentuan
sebagaimana diberlakukan pada
bank konvensional

Penilaian kinerja bank umum syariah juga menggunakan faktor permodalan dengan rasio Capital Adequacy Ratio (CAR), faktor kualitas aset dengan rasio Non Performing Financing (NPF), faktor rentabilitas dengan rasio Returm On Asset (ROA) dan Beban Operasional Pendapatan Operasional (BOPO), serta faktor likuiditas dengan rasio Financing to Deposit Ratio (FDR).

Rumusan masalah dalam penelitian ini adalah apakah terdapat perbedaan kinerja keuangan antara bank umum syariah hasil spin off dan akuisisi periode 2013-2015?

Tujuan penelitian ini adalah untuk mengetahui perbandingan kinerja antara bank umum syariah hasil spin off dan hasil akuisisi periode 2013-2015.

\section{LANDASAN TEORI DAN PENGEMBANGAN HIPOTESIS}

Bank syari'ah adalah bank yang beroperasi dengan tidak mengandalkan pada bunga (Muhammad, 2005:!). Fungsi dasar bank adalah sebagai tempat untuk menitipkan vang dengan aman dan sebagai tempat alat pembayaran untuk membeli barang dan jasa. Perbankan syariah salah satunya berdiri karena alasan filosofis seperti pelarangan riba. Pelarang riba dalam perbankan syariah ini tertuang dalam QS. Ali-Imron ayat 130 yang berbunyi:

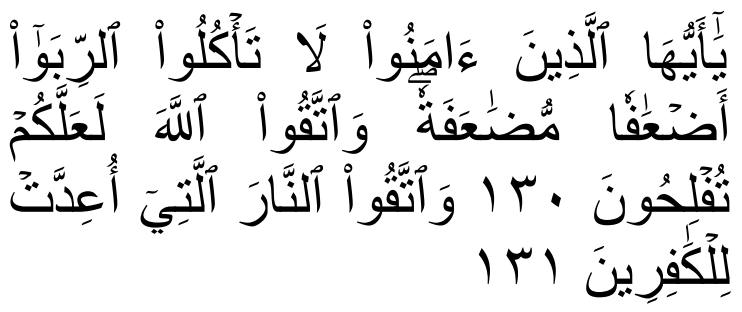

Yā ayyuhal-lażina āmanū lā ta'kulur-ribā aḍ'āfammu dọ'afah, wattaqullāha la'allakum tuflihūn.Wattaqun-nārallatī u'iddat lil-kāfirīn

Artinya: Wahai orang-orang yang beriman! Janganlah kamu memakan riba dengan berlipat ganda dan bertakwalah kepada Allah agar kamu beruntung.Dn peliharalah dirimu dari api neraka, yang disediakan untuk orang-orang yang kafir (Departemen Agama RI, 2012:66)

Tafsir ayat diatas menjelaskan bahwa larangan seseorang untuk memakan riba dengan berlipat ganda dan apabila larangan orang tersebut tetap dilanggar, maka yang akan didapatkan adalah api neraka yang 
Hisyam, et al/Jurnal Ekonomi Syariah Teori dan Terapan Vol. 3 No. 11 November 2016: 872-886; ANALISIS PERBANDINGAN KINERJA KEUANGAN BANK UMUM SYARIAH HASIL SPIN OFF DAN NON SPIN OFF PERIODE 2013-2015

disediakan untuk orang-orang yan kafir (Quthb, 2000:257).

Sejak diberlakukannya UndangUndang Nomor 21 Tahun 2008 tentang Perbankan Syariah, persoalan pengembangan perbankan syariah melalui mekanisme baru, yakni mekanisme akuisisi dan konversi bank konvensional menjadi syariah.

Menurut Anshori (2010:62)
Implementasinya dapat dilakukan
melalui tiga pendekatan yakni:
Pertama, Bank Umum Konvensional (BUK) yang telah memiliki Unit Usaha Syariah (UUS), mengakuisisi bank yang ralatif kecil dan mengkonversinya menjadi syariah dan melepaskan serta menggabungkan UUSnya dengan bank yang baru dikonversi tersebut. Kedua, BUK yang belum memiliki UUS, mengakui bank yang relatif kecil dan mengkonversinya menjadi syariah. Ketiga, BUK melakukan pemisahan (spin off) UUS dan dijadikan Bank Umum Syariah (BUS) tersendiri.

1. Spin Off

$$
\begin{aligned}
& \text { Menurut Mulhadli (2010:28) } \\
& \text { sebenarnya praktek spin-off telah } \\
& \text { cukup lama dikenal sebagai satu } \\
& \text { bagian konstruksi yang banyak } \\
& \text { digunakan dalam merestrukrisasi } \\
& \text { hukum. }
\end{aligned}
$$

Pemisahan (spin off) telah diatur dalam Peraturan Bank Indonesia No. 11/10/2009 tentang Unit Usaha Syariah dalam pasal 40, 41 dan 45 tentang persyaratan jangka waktu, jumlah aset, dan modal disetor.

\section{Akuisisi}

Istilah akuisisi cenderung untuk memiliki konotasi negatif dibanding positif. Di Indonesia istilah ini sering dikaitkan dengan masalah monopoli (Sutojo, 1992: 45).

\begin{abstract}
Pengambilalihan telah diatur dalam Peraturan Bank Indonesia No. 11/3/2009 tentang Bank Umum Syariah pada pasal 5 dan pasal 18 tentang modal disetor diikuti dengan Peraturan
\end{abstract} Pemerintah Indonesia No.28 tahun 1999 tentang Merger, Konsolidasi dan Akuisisi Bank pada pasal 1 dan pasal 9 tentang pengambilalihan aset.

Kinerja menunjukkan sesatu yang berhubungan dengan kekuatan serta kelemahan suatu perusahaan. Kekuatan tersebut dipahami agar dapat dimanfaatkan dan kelemahan pun harus diketahui agar dapat dilakukan langkah-langkah perbaikan (Lestari dan Sugiharto: 2007) dalam Ashar (2010:33).

Kasmir (2013:104) menyatakan bahwa rasio keuangan adalah kegiatan membandingkan angkaangka yang terdapat dalam laporan kevangan dengan cara membagi satu angka dengan angka lainnya. Setelah mengetahui hasil dari rasiorasio tersebut maka kondisi keuangan dari bank syariah akan terlihat.

1. Faktor Permodalan (Capital)

Penilaian faktor permodalan
digunakan untuk mengetahui
kecukupan modal bank dalam
mendukung kegiatan operasional
bank (Jumingan, 2006:243).
Menurut Lestari dan Rahyuda
(2011), faktor permodalan dapat diukur dengan menggunakan KPMM (Kewajiban Penyediaan Modal Minimum) atau rasio CAR (Capital Adequency Ratio) dengan rumus sebagai berikut:

$\operatorname{KPMM}(\mathrm{CAR})=\frac{\text { Modal }}{\mathrm{ATMR}} \times 100 \%$

\section{Keterangan:}

KPMM = Kewajiban Penyediaan Modal Minimum 
Hisyam, et al/Jurnal Ekonomi Syariah Teori dan Terapan Vol. 3 No. 11 November 2016: 872-886; ANALISIS PERBANDINGAN KINERJA KEUANGAN BANK UMUM SYARIAH HASIL SPIN OFF DAN NON SPIN OFF PERIODE 2013-2015

CAR = Capital Adequecy Ratio

ATMR = Aktiva Terhitung Menurut Risiko

Menurut Taswan (2006: 228), penurunan pada rasio kecukupan modal bermakna negatif karena menunjukkan ketidak mampuan bank dalam mengcover risiko dan dapat mengganggu stabilitas perbankan.

Oleh karena itu, Bank Indonesia menetapkan kebijakan bahwa penediaan modal minimum bank diukur dari presentase tertentu terhadap Aktiva Tertimbang Menurut Risiko (ATMR) sebesar $8 \%$ dari ATMR.

2. Faktor Kualitas Aset (Asset)

Menurut Jumingan (2006:243), penilaian faktor kualitas aset digunakan untuk mengukur efisiensi manajemen dalam menggunakan aset yang dimiliki bank.

Pengertian aktiva produktif menurut Surat Keputusan Direksi Bank Indonesia Nomor 13/147/KEP/DIR tanggal 12 November 1998 tentang Kualitas Aktiva Produktif adalah penanaman bank dalam rupiah maupun valas dalam bentuk kredit, surat berharga, penempatan dana antar bank, penyertaan, komitmen dan kotinjensi pada transaksi rekening administratif (Taswan, 2006: 451).

Menurut Surat Edaran Bank Indonesia 9/24/Dpbs tahun 2007, rasio yang digunakan untuk menilai faktor Kualitas Aset Produktif adalah Non Performing Financing (NPF) dengan rumus sebagai berikut:

NPF $=\frac{\text { Pembiayaan }(K L, D, M)}{\text { Total Pembiayaan }} \times 100 \%$

Keterangan:

NPF = Non Performing Financing

Pembiayaan $\mathrm{KL}=$ Pembiayaan Kurang Lancar

Pembiayaan D = Pembiayaan Diragukan
Pembiayaan $M=$ Pembiayaan Macet

Berdasarkan Surat Edaran Bank Indonesia Nomor 9/24/DPbs tahun 2007, tujuan dari rasio NPF adalah untuk mengukur tingkat permasalahan pembiayaan yang dihadapi oleh bank. Semakin tinggi NPF, menunjukkan kualitas pembiayaan yang dimiliki bank umum syariah tersebut yang semakin buruk dikarenakan tingginya jumlah pembiayaan bermasalah.

3. Faktor Rentabilitas (Earning)

Analisis rasio rentabilitas bank adalah alat ukur untuk mengukur tingkat efisisensi usaha dan profitabilitas yang dicapai oleh bank yang bersangkutan (Dendawijaya, 2003:119-120).

Menurut Surat Edaran Bank Indonesia 9/24/Dpbs tahun 2007, rasio yang digunakan untuk menilai faktor rentabilitas dapat diukur menggunakan dua rasio, yaitu:

a. $\mathrm{ROA}=\frac{\text { Laba Sebelum Pajak }}{\text { Rata-rata Total Aset }} \times 100 \%$

Menurut Surat Edaran Bank Indonesia Nomor 9/24/DPbs tahun 2007, tujuan dari rasio ROA adalah untuk mengukur keberhasilan manajemen dan menghasilkann laba.

b. $\mathrm{BOPO}=\frac{\text { Beban Operasional }}{\text { Pendapatan Operasional }} \times 100 \%$

Menurut Surat Edaran Bank Indonesia No.9/24/DPbS tahun 2007, rasio BOPO bertujuan untuk mengukur tingkat efisiensi dan kemampuan bank dalam melakukan kegiatan operasionalnya sebagai penghimpun dan penyaluran dana masyarakat.

4. Faktor Likuiditas (Liquidity) 
Hisyam, et al/Jurnal Ekonomi Syariah Teori dan Terapan Vol. 3 No. 11 November 2016: 872-886; ANALISIS PERBANDINGAN KINERJA KEUANGAN BANK UMUM SYARIAH HASIL SPIN OFF DAN NON SPIN OFF PERIODE 2013-2015

Kegunaan faktor likuiditas adalah kemampuan bank untuk memenuhi kewajibannya, terutama kewajiban jangka panjang pendek (Arifin (2006:78).

Menurut Lestari dan Rahyuda (2011), rasio yang digunakan untuk menilai faktor Likuiditas menggunakan rasio Financing to Deposits Ratio (FDR) dengan rumus sebagai berikut:

FDR $=\frac{\text { Total Pembiayaan }}{\text { Total Dana Pihak Ketiga }} \times 100 \%$

Keterangan:

FDR = Financing to Deposits Ratio

Semakin tinggi rasio tersebut memberikan indikasi semakin rendahnya kemampuan likuiditas bank dikarenakan jumlah dana yang diperlukan untuk membiayai kredit juga semakin besar.

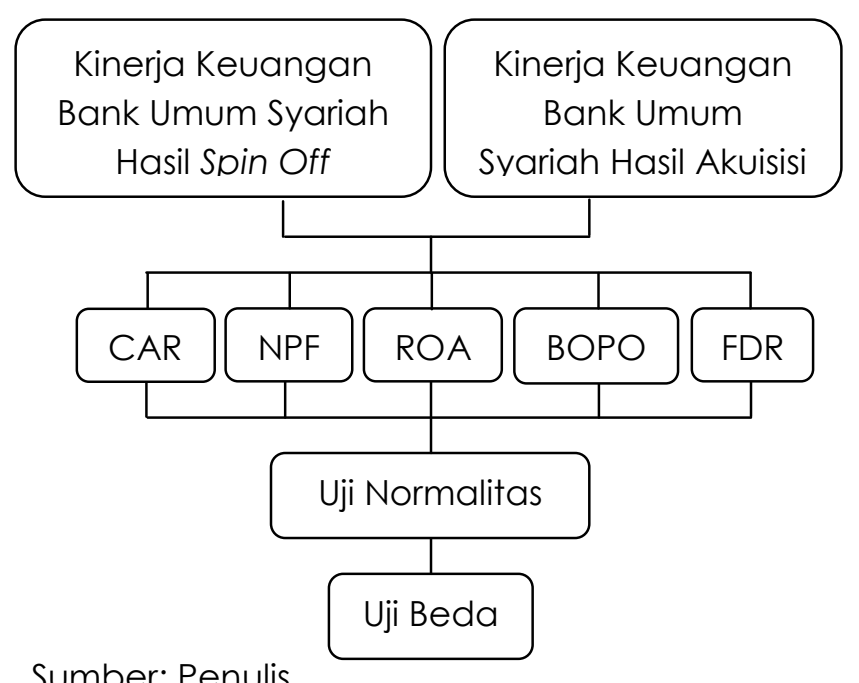

\section{Gambar 1}

Model Analisis

Hipotesis dalam penelitian ini adalah sebagai berikut:

$\mathrm{H}_{0}$ : Tidak terdapat perbedaan signifikan pada kinerja keuangan bank umum syariah hasil spin off dan hasil akuisisi dilihat dari rasio CAR, ROA, BOPO, NPF dan FDR.

$\mathrm{H}_{1}$ : Terdapat perbedaan signifikan pada kinerja keuangan bank umum syariah hasil spin off dan hasil akvisisi dilihat dari rasio CAR, ROA, BOPO, NPF dan FDR.

\section{METODE PENELITIAN}

\section{Pendekatan Penelitian}

Pendekatan yang dipergunakan dalam penelitian ini adalah pendekatan kuantitatif.

Teknik analisis yang digunakan adalah statistik deskriptif, yaitu teknik statistik yang digunakan untuk menganalisis data dengan mendeskripsikan data yang telah terkumpul sebelumnya (Anshori dan Iswati, 2009:116).

\section{Identifikasi Variabel}

Variabel merupakan karakter atau sifat dari obyek kajian yang relevan dengan permasalahan penelitian (Solimun, 2002:3). Berdasarkan rumusan masalah, maka variabel dalam penelitian ini adalah (1) Capital Adequacy Ratio (CAR), (2) Non Performing Financing (NPF), (3) Return on Asset (ROA), (4) Beban Operasional Pendapatan Operasional (BOPO) dan (5) Financing Deposit Ratio (FDR).

\section{Definisi Operasional}

Anshori dan Iswati (2009:60) menyebutkan definisi operasional adalah suatu definisi yang diberikan kepada suatu variabel dengan cara memberikan arti, atau menspesifikasikan kegiatan yang diperlukan untuk mengukur variabel tersebut.

Definisi operasional mengandung penjelasan/spesifikasi mengenai variabel yang telah diidentifikasi, pengukuran variabel, dan skala/ukuran yang digunakan. Definisi operasional dari 
Hisyam, et al/Jurnal Ekonomi Syariah Teori dan Terapan Vol. 3 No. 11 November 2016: 872-886; ANALISIS PERBANDINGAN KINERJA KEUANGAN BANK UMUM SYARIAH HASIL SPIN OFF DAN NON SPIN OFF PERIODE 2013-2015

variabel yang digunakan dalam penelitian ini adalah sebagai berikut:

1. Capital Adequacy Ratio (CAR)

Rasio CAR adalah salah satu rasio yang digunakan dalam mengukur faktor permodalan dengan membandingkan antara modal yang dimiliki bank dengan aktiva tertimbang menurut risikonya. Data ini merupakan data rasio yang diambil dari laporan kevangan semesteran 30 Juni 2013 hingga 30 Juni 2015.

2. Non Performing Financing (NPF)

Rasio NPF adalah salah satu rasio yang digunakan dalam mengukur faktor kualitas aset dengan membandingkan pembiayaan bermasalah yang dimiliki bank dengan total pembiayaannya. Data ini merupakan data rasio yang diambil dari laporan keuangan semesteran 30 Juni 2013 hingga 30 Juni 2015.

3. Return on Asset (ROA)

Rasio ROA adalah salah satu rasio yang digunakan dalam mengukur faktor rentabilitas dengan membandingkan jumlah laba sebelum pajak yang dimiliki bank dengan total asetnya. Data ini merupakan data rasio yang diambil dari laporan keuangan semesteran 30 Juni 2013 hingga 30 Juni 2015.

4. Beban Operasional Pendapatan Operasional (BOPO)

Rasio BOPO adalah salah satu rasio yang digunakan dalam mengukur faktor rentabilitas dengan membandingkan tingkat beban operasional yang dimiliki bank dengan pendapatan operasionalnya. Data ini merupakan data rasio yang diambil dari laporan keuangan semesteran 30 Juni 2013 hingga 30 Juni 2015.

5. Financing Deposit Ratio (FDR)

Rasio FDR adalah salah satu rasio yang digunakan dalam mengukur faktor likuiditas dengan membandingkan total pembiayaan yang dimiliki bank dengan total dana pihak ketiganya. Data ini merupakan data rasio yang diambil laporan keuangan semesteran 30 Juni 2013 hingga 30 Juni 2015.

\section{Jenis dan Sumber Data}

Jenis data yang dipergunakan dalam penelitian ini menggunakan data sekunder. Data yang digunakan berupa laporan keuangan semesteran 30 Juni 2013 hingga 30 Juni 2015 yang telah dipublikasi di website bank umum syariah terkait. Variabel yang digunakan dalam penelitian berupa rasio yang telah dipublikasikan dalam laporan keuangan tersebut. Pengumpulan data penelitian ini dilakukan secara panel data (pooled data), karena dilakukan dengan melibatkan banyak sampel pada tiap periodenya (cross section) dan melibatkan urutan waktu (time series).

\section{Populasi dan Sampel}

Menurut Anshori dan Iswati (2009:92), populasi adalah wilayah generalisasi yang terdiri atas subyek yang mempunyai kualitas dan karakteristik tertentu yang ditetapkan oleh peneliti untuk dipelajari dan kemudian ditarik kesimpulannya. 
Hisyam, et al/Jurnal Ekonomi Syariah Teori dan Terapan Vol. 3 No. 11 November 2016: 872-886; ANALISIS PERBANDINGAN KINERJA KEUANGAN BANK UMUM SYARIAH HASIL SPIN OFF DAN NON SPIN OFF PERIODE 2013-2015

Pada penelitian ini, teknik pengambilan sampel yang digunakan adalah purposive sampling. Anshori dan Iswati (2009:105), menyatakan bahwa sampling purposive adalah teknik penentuan sampel dengan pertimbangan tertentu.

Populasi yang digunakan dalam penelitian ini adalah untuk bank umum syariah hasil spin off terdapat Bank BNI Syariah, B.PD Jawa Barat dan Banten Syariah, dan Bank Tabungan Pensiunan Nasional Syariah. Sedangkan populasi untuk bank umum syariah hasil akuisisi adalah Bank Victoria Syariah, Bank Mega Syariah, Bank Panin Syariah dan Bank BCA Syariah, Bank Bukopin Syariah dan Bank Syariah Mandiri. Adapun kriteria pemilihan sampel penelitian ini adalah sebagai berikut:

1. Bank umum syariah yang merupakan hasil spin off dari unit usaha syariah bank umum konvensional serta hasil akuisisi.

2. Bank umum syariah yang telah berdiri pada tahun 2013.

3. Bank umum syariah yang mempublikasikan laporan keuangan semesteran 30 Juni 2013 hingga 30 Juni 2015.

Maka dari ketentuan kriteria pemilihan sampel penelitian diatas maka dapat diambil kesimpulan terdapat 7 bank umum syariah hasil spin off dan akuisisi yang menjadi sampel dari penelitian ini.
Tabel 1

Sampel Penelitian

\begin{tabular}{|l|l|}
\hline \multicolumn{1}{|c|}{$\begin{array}{c}\text { Nama Bank Umum } \\
\text { Syariah }\end{array}$} & \multicolumn{1}{|c|}{$\begin{array}{c}\text { Kategori } \\
\text { Sampel }\end{array}$} \\
\hline Bank BNI Syariah & Spin Off \\
\hline Bank Mega Syariah & Akuisisi \\
\hline Bank Panin Syariah & Akuisisi \\
\hline Bank BCA Syariah & Akuisisi \\
\hline Bank BRI Syariah & Akuisisi \\
\hline Bank Syariah Bukopin & Akuisisi \\
\hline Bank Syariah Mandiri & Akuisisi \\
\hline \multicolumn{2}{|l|}{ Sumber: Diolah oleh Peneliti }
\end{tabular}

Teknik Analisis

Teknik analisis data dalam penelitian kuantitatif menggunakan analisis statistik. Analisis data dalam penelitian ini menggunakan dua tahap, yakni statistik deskriptif dan statistik inferensial. Statistik deskriptif adalah metode mengatur, merangkum, dan mempresentasikan data dengan cara yang informatif (Lind, 2013:6).

Statistik deskriptif menyajikan nilai rata-rata (mean), nilai terendah (minimum) dan nilai tertinggi (maximum) dari rasio-rasio yang diujikan yaitu rasio CAR, ROA, BOPO, NPF dan FDR yang dimiliki bank yang mejadi sampel selama periode 2013-2015. Statistik deskriptif pada penelitian ini menggunakan program Ms.Excel 2007.

Menurut Santoso (2013:241), metode statistik inferensi dalam praktik cukup beragam, dan salah satu kriteria penting dalam pemilihan metode statistik yang akan digunakan adalah melihat distribusi sebuah data. Jika data yang diuji berdistribusi normal atau mendekati distribusi normal, selanjutnya dengan data-data tersebut bisa dilakukan berbagai inferensi atau pengambilan keputusan dengan metode statistik parametrik. Namun, jika terbukti data tidak berdistribusi normal atau jauh dari kriteria distribusi normal, maka 
Hisyam, et al/Jurnal Ekonomi Syariah Teori dan Terapan Vol. 3 No. 11 November 2016: 872-886; ANALISIS PERBANDINGAN KINERJA KEUANGAN BANK UMUM SYARIAH HASIL SPIN OFF DAN NON SPIN OFF PERIODE 2013-2015

metode parametrik tidak bisa digunakan untuk kegiatan inferensi sebaiknya digunakan metode nonparametrik.

Statistik inferensial dalam penelitian ini menggunakan analisis parametrik dengan uji t Test dan juga analisis non parametrik dengan Mann-Whitney test dengan menggunakan aplikasi SPSS 19. Analisis ini bertujuan untuk mengetahui perbedaan nyata antara dua rata-rata populasi (Santoso, 2013:244).

\section{HASIL DAN PEMBAHASAN}

\section{Deskripsi Hasil Penelitian}

1. Deskripsi CAR

Pada nilai rata-rata, maksimum dan nilai minimum pada mean rasio CAR untuk bank umum syariah hasil spin off dan akuisisi terlihat bahwa rasio CAR untuk bank umum syariah hasil akuisisi lebih besar dibandingkan dengan bank umum syariah hasil spin off. Sehingga dapat disimpulkan bahwa bank umum syariah hasil akuisisi memiliki kinerja keuangan yang lebih baik dari dilihat dari rasio CAR.

\section{Deskripsi NPF}

Pada nilai rata-rata, maksimum dan nilai minimum pada mean rasio NPF untuk bank umum syariah hasil spin off dan akuisisi terlihat bahwa rasio NPF untuk bank umum syariah hasil spin off lebih kecil dibandingkan dengan bank umum syariah hasil akuisisi. Sehingga dapat disimpulkan bahwa bank umum syariah hasil spin off memiliki kinerja keuangan yang lebih baik dilihat dari rasio NPF.

3. Deskripsi ROA
Pada nilai rata-rata dan minimum pada mean rasio ROA untuk bank umum syariah hasil spin off dan akvisisi terlihat bahwa rasio ROA untuk bank umum syariah hasil spin off lebih besar dibandingkan dengan bank umum syariah hasil akuisisi. Sehingga dapat disimpulkan bahwa bank umum syariah hasil spin off memiliki kinerja keuangan yang lebih baik dilihat dari rasio ROA pada nilai rata-rata dan minimum, kecuali nilai maksimum.

\section{Deskripsi BOPO}

Pada nilai rata-rata dan maksimum pada mean rasio BOPO untuk bank umum syariah hasil spin off dan akvisisi terlihat bahwa rasio BOPO untuk bank umum syariah hasil spin off lebih kecil dibandingkan dengan bank umum syariah hasil akuisisi. Sehingga dapat disimpulkan bahwa bank umum syariah hasil spin off memiliki kinerja keuangan yang lebih baik dilihat dari rasio BOPO pada nilai rata-rata dan maksimum, kecuali nilai minimum karena pada nilai minimum untuk bank umum syariah hasil akuisisi lebih unggul.

\section{Deskripsi FDR}

Pada nilai rata-rata dan maksimum pada mean rasio FDR untuk bank umum syariah hasil spin off dan akuisisi terlihat bahwa rasio FDR untuk bank umum syariah hasil spin off lebih kecil dibandingkan dengan bank umum syariah hasil akvisisi. Sehingga dapat disimpulkan bahwa bank umum syariah hasil spin off memiliki kinerja keuangan yang lebih baik dilihat dari rasio FDR pada 
Hisyam, et al/Jurnal Ekonomi Syariah Teori dan Terapan Vol. 3 No. 11 November 2016: 872-886; ANALISIS PERBANDINGAN KINERJA KEUANGAN BANK UMUM SYARIAH HASIL SPIN OFF DAN NON SPIN OFF PERIODE 2013-2015

nilai rata-rata dan maksimum, kecuali pada nilai minimum.

Maka dapat disimpulkan dari hasil analisis statistik deskriptif bahwa bank umum syariah hasil spin off memiliki kinerja keuangan yang lebih baik dibandingkan dengan bank umum syariah hasil akuisisi dilihat dari rasio tersebut.

\section{Uji Normalitas}

Tabel 2

Uji Normalitas

\begin{tabular}{|ll|r|r|c|}
\hline \multirow{2}{*}{} & & \multicolumn{3}{|c|}{ Kolmogorov-Smirnova } \\
\cline { 3 - 5 } & Kategori & Statistic & \multicolumn{1}{c|}{ df } & \multicolumn{1}{l|}{ Sig. } \\
\hline \multirow{2}{*}{ CAR } & Spin Off & .219 & 5 & $.200^{*}$ \\
\cline { 2 - 5 } & Akuisisi & .201 & 30 & .003 \\
\hline \multirow{2}{*}{ NPF } & Spin Off & .209 & 5 & $.200^{*}$ \\
\cline { 2 - 5 } & Akuisisi & .168 & 30 & .030 \\
\hline \multirow{2}{*}{ ROA } & Spin Off & .225 & 5 & $.200^{*}$ \\
\cline { 2 - 5 } & Akuisisi & .132 & 30 & .191 \\
\hline \multirow{2}{*}{ BOPO } & Spin Off & .255 & 5 & $.200^{*}$ \\
\cline { 2 - 5 } & Akuisisi & .110 & 30 & $.200^{*}$ \\
\hline \multirow{2}{*}{ FDR } & Spin Off & .237 & 5 & $.200^{*}$ \\
\cline { 2 - 5 } & Akuisisi & .242 & 30 & .000 \\
\hline
\end{tabular}

Sumber: Output SPSS 19

Kesimpulan dari uji normalitas adalah untuk variabel ROA dan BOPO telah terdistribusi normal, sedangkan untuk variabel CAR, NPF dan FDR tidak terdistribusi normal. Maka untuk variabel ROA dan BOPO dapat dilanjutkan uji beda dengan menggunakan uji $t$, sedangkan pada variabel CAR, NPF dan FDR dapat dilanjutkan dengan uji beda Mann-Whitney.

\section{Uji Beda}

1. Uji Beda CAR

Berikut merupakan hasil dari uji beda variabel CAR dengan menggunakan Mann-Whitney test.
Tabel 3

Uji Beda Mann-Whitney Variabel CAR

\begin{tabular}{|l|c|c|}
\hline \multicolumn{1}{|c|}{ Kategori } & Mean Rank & Sig \\
\hline Spin Off & 20,20 & \multirow{2}{*}{0,631} \\
\hline Akuisisi & 17,63 & \\
\hline
\end{tabular}

Sumber: Output SPSS 19

Berdasarkan uji beda MannWhitney Test yang dilakukan pada variabel CAR untuk bank umum syariah hasil spin off dan akuisisi, diketahui bahwa nilai signifikansi dari variabel ini adalah sebesar 0,631 yang lebih besar dari 0,05 sehingga menunjukkan bahwa tidak terdapat perbedaan kinerja keuangan antara bank umum syariah hasil spin off dan hasil akuisisi pada sisi CAR.

2. Uji Beda NPF

Tabel 4

Uji Beda Mann-Whitney Variabel NPF

\begin{tabular}{|l|c|c|}
\hline \multicolumn{1}{|c|}{ Kategori } & Mean Rank & Sig \\
\hline Spin Off & 13,00 & \multirow{2}{*}{0,257} \\
\hline Akuisisi & 18,83 & \\
\hline
\end{tabular}

Sumber: Output SPSS 19

Hasil uji beda Mann-Whitney yang dilakukan pada variabel NPF untuk bank umum syariah hasil spin off dan akuisisi, diketahui bahwa nilai signifikansi dari variabel ini adalah sebesar 0,257 yang lebih besar dari 0,05 sehingga menunjukkan bahwa tidak terdapat perbedaan kinerja keuangan antara bank umum syariah hasil spin off dan hasil akuisisi pada sisi NPF.

3. Uji Beda ROA

Variabel ROA mempunyai data terdistribusi normal maka dilanjutkan dengan uji Independent sample t-test. Variabel ini memiliki nilai signifikansi dari Levene's test sebesar 0,031 yang kurang besar dari 0,05 , sehingga hasil uji yang 
Hisyam, et al/Jurnal Ekonomi Syariah Teori dan Terapan Vol. 3 No. 11 November 2016: 872-886; ANALISIS PERBANDINGAN KINERJA KEUANGAN BANK UMUM SYARIAH HASIL SPIN OFF DAN NON SPIN OFF PERIODE 2013-2015

digunakan adalah equal variances not assumed.

Tabel 5

Uji Beda Independent Sample t-Test Variabel ROA

\begin{tabular}{|c|c|c|c|}
\hline \multirow{2}{*}{} & \multicolumn{2}{|c|}{ Levene's Test } & \multirow{2}{*}{ Sig. } \\
\cline { 3 - 3 } & $\mathrm{F}$ & Sig. & \\
\hline $\begin{array}{c}\text { Equal variances } \\
\text { assumed }\end{array}$ & 5,312 & 0,031 & 0,427 \\
\cline { 1 - 1 } $\begin{array}{c}\text { Equal variances } \\
\text { not assumed }\end{array}$ & & 0,065 \\
\hline
\end{tabular}

Sumber: Output SPSS 19

Berdasarkan uji Independent Sample t-Test yang dilakukan pada variabel ROA untuk bank umum syariah hasil spin off dan akuisisi, diketahui bahwa nilai signifikansi dari variabel ini adalah sebesar 0,065 yang lebih besar dari 0,05 sehingga menunjukkan bahwa tidak terdapat perbedaan kinerja keuangan antara bank umum syariah hasil spin off dan hasil akuisisi pada sisi ROA.

4. Uji Beda BOPO

Tabel 6

Uji Beda Independent Sample t-Test Variabel BOPO

\begin{tabular}{|c|c|c|c|}
\hline & \multicolumn{2}{|c|}{ Levene's Test } & \multirow{2}{*}{ Sig. } \\
\cline { 2 - 3 } & $\mathrm{F}$ & Sig. & \\
\hline $\begin{array}{c}\text { Equal variance } \\
\text { assumed }\end{array}$ & 3,952 & 0,055 & 0,423 \\
\cline { 1 - 1 } $\begin{array}{c}\text { Equal variance } \\
\text { not assumed }\end{array}$ & & 0,111 \\
\hline
\end{tabular}

Sumber: Output SPSS 19

Variabel ini memiliki nilai signifikansi dari Levene's test sebesar 0,055 yang lebih besar dari 0,05, sehingga hasil uji yang digunakan adalah equal variances assumed. Berdasarkan uji Independent Sample t-Test yang dilakukan pada variabel BOPO untuk bank umum syariah hasil spin off dan akuisisi, diketahui bahwa nilai signifikansi dari variabel ini adalah sebesar 0,055 yang lebih besar dari 0,05 sehingga menunjukkan bahwa tidak terdapat perbedaan kinerja keuangan antara bank umum syariah hasil spin off dan hasil akuisisi pada sisi BOPO.

5. Uji Beda FDR

Tabel 7

Uji Beda Mann-Whitney Variabel FDR

\begin{tabular}{|l|c|c|}
\hline \multicolumn{1}{|c|}{ Kategori } & Mean Rank & Sig \\
\hline Spin Off & 20,80 & \multirow{2}{*}{0,536} \\
\hline Akuisisi & 17,20 & \\
\cline { 1 - 2 }
\end{tabular}

Sumber: Output SPSS 19

Hasil uji beda Mann-Whitney yang dilakukan pada variabel FDR untuk bank umum syariah hasil spin off dan akuisisi, diketahui bahwa nilai signifikansi dari variabel ini adalah sebesar 0,536 yang lebih besar dari 0,05 sehingga menunjukkan bahwa tidak terdapat perbedaan kinerja keuangan antara bank umum syariah hasil spin off dan hasil akuisisi pada sisi FDR.

\section{Pembahasan}

\section{Tabel 8}

Hasil Uji Beda Semua Variabel

\begin{tabular}{|c|c|}
\hline Variabel & Hasil Uji Beda \\
\hline CAR & Tidak terdapat perbedaan \\
\hline NPF & Tidak terdapat perbedaan \\
\hline ROA & Tidak terdapat perbedaan \\
\hline BOPO & Tidak terdapat perbedaan \\
\hline FDR & Tidak terdapat perbedaan \\
\hline
\end{tabular}

Sumber: Diolah oleh Peneliti

1. CAR

Rasio CAR mempunyai penilaian semakin besar nilai dari rasio CAR, maka bank tersebut memiliki kinerja keuangan yang baik dilihat dari sisi rasio CAR. Hasil yang menunjukkan tidak terdapatnya perbedaan pada rasio CAR yang dimiliki bank umum syariah hasil spin off dan akuisisi disebabkan oleh adanya 
Hisyam, et al/Jurnal Ekonomi Syariah Teori dan Terapan Vol. 3 No. 11 November 2016: 872-886; ANALISIS PERBANDINGAN KINERJA KEUANGAN BANK UMUM SYARIAH HASIL SPIN OFF DAN NON SPIN OFF PERIODE 2013-2015

ketentuan dari Bank Indonesia bahwa bank yang beroperasi di Indonesia harus memiliki rasio Kewajiban Pemenuhan Modal Minimum (KPMM) atau CAR dengan nilai minimum sebesar $8 \%$.

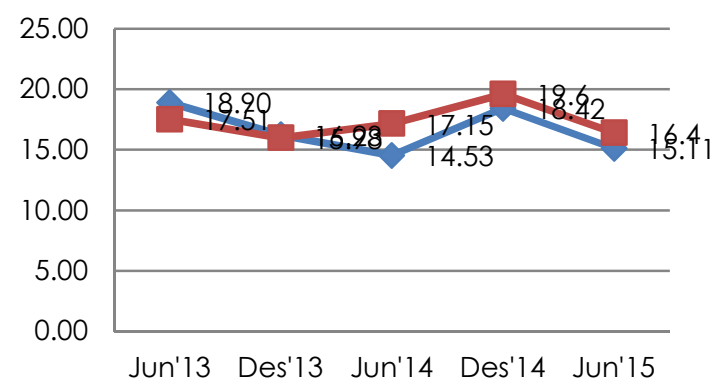

$\smile$ Spin Off

Sumber: Diolah oleh Peneliti - Akvisisi Gambar 2 Perkembangan Mean CAR

2. NPF

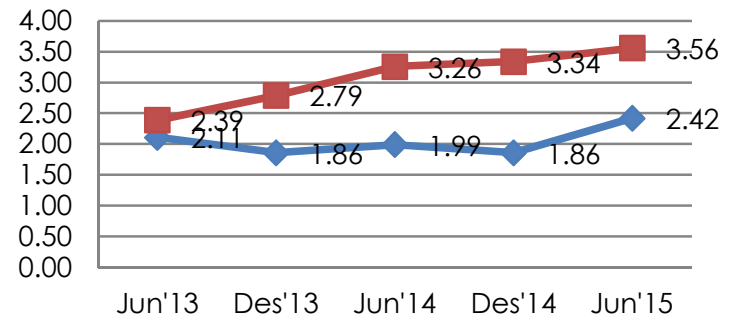

Sumber: Diolah oleh Peneliti

$$
\longrightarrow \text { Spin Off }
$$

Gambar 3

\section{Perkembangan Mean NPF}

Rasio NPF mempunyai penilaian bahwa semakin kecil nilai dari rasio tersebut maka semakin baik kinerja bank umum syariah dari segi NPF. Bank umum syariah hasil spin off mempunyai rasio NPF yang lebih baik karena mempunyai nilai mean rasio NPF per periode penelitian yang lebih kecil dibandingkan dengan bank umum syariah hasil akuisisi.
Tidak terdapatnya perbedaan dari segi rasio NPF yang dimiliki bank umum syariah hasil spin off dan akuisisi disebabkan oleh adanya ketentuan dari Bank Indonesia bahwa bank yang beroperasi di Indonesia harus memiliki rasio NPF dengan nilai minimum sebesar $5 \%$.

3. $R O A$

Semakin tinggi rasio ROA pada bank umum syariah, maka menggambarkan kinerja bank umum syariah yang semakin baik pula dalam menghasilkan laba.
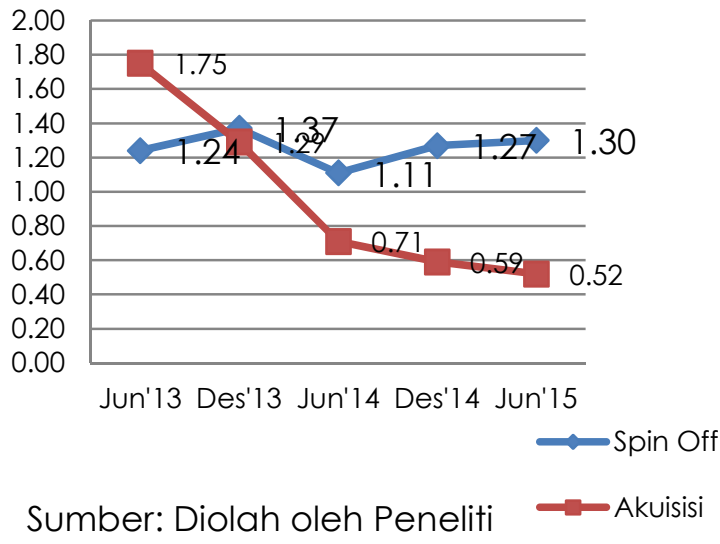

Gambar 4

Perkembangan Mean Rasio ROA

Bank umum syariah hasil spin off mempunyai rasio ROA yang lebih baik karena mempunyai nilai mean rasio ROA per periode penelitian yang lebih besar dibandingkan dengan bank umum syariah hasil akuisisi.

Tidak terdapatnya perbedaan dari segi rasio ROA yang dimiliki bank umum syariah hasil spin off dan akuisisi disebabkan oleh adanya ketentuan dalam kepemilikan aset saat pendirian bank umum syariah. Pada bank umum 
Hisyam, et al/Jurnal Ekonomi Syariah Teori dan Terapan Vol. 3 No. 11 November 2016: 872-886; ANALISIS PERBANDINGAN KINERJA KEUANGAN BANK UMUM SYARIAH HASIL SPIN OFF DAN NON SPIN OFF PERIODE 2013-2015

syariah hasil spin off diterapkan adalah Peraturan Bank Indonesia No.11/10/2009 tentang Unit Usaha Syariah (UUS) pada pasal 40 bahwa UUS wajib memisahkan (spin off) BUS apabila nilai aset UUS telah mencapai $50 \%$ dari total nilai aset induknya. Pada bank umum syariah hasil akuisisi diterapkan adalah Peraturan Pemerintah Republik Indonesia No.28 tahun 1999 tentang Merger, Konsolidasi dan akuisisi bank pada pasal 9 bahwa pengambilalihan saham bank, yang mengakibatkan kepemilikan saham oleh pemegang saham perorangan atau badan hukum menjadi lebih dari $25 \%$ dari saham bank yang telah dikeluarkan dan mempunyai hak suara.

4. BOPO

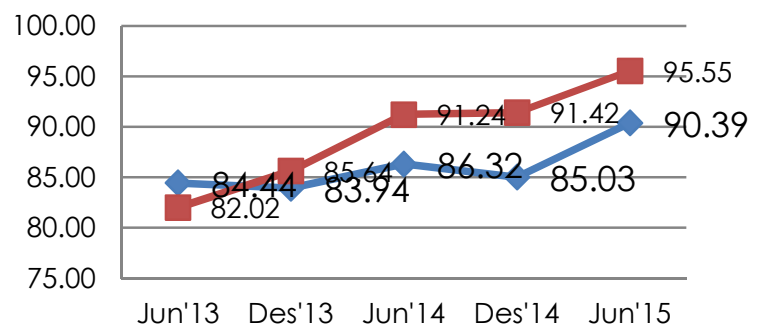

Sumber: Diolah oleh Peneliti $\longrightarrow$ Akuisisi

Gambar 5

Perkembangan Mean Rasio BOPO

Penilaian pada rasio ini adalah jika bank umum syariah memiliki nilai rasio BOPO yang lebih rendah, maka bank umum syariah tersebut memiliki kinerja yang lebih baik. Bank umum syariah hasil spin off mempunyai rasio BOPO yang lebih baik karena mempunyai nilai mean rasio BOPO per periode penelitian yang lebih kecil dibandingkan dengan bank umum syariah hasil akuisisi.

Tidak terdapatnya perbedaan dari segi rasio BOPO pada bank umum syariah hasil spin off dan hasil akuisisi disebabkan oleh bank umum konvensional tidak akan melepaskan menjadi bank umum syariah tanpa melalui proses pembinaan manajemen dan pengelolaan operasional bank agar nantinya bank umum syariah dapat tetap berlangsung dengan kinerja yang baik, termasuk dalam manajemen efisiensi dengan selalu mengimbangi beban operasional dengan pendapatan operasionalnya.

5. FDR

Rasio FDR memiliki penilaian bahwa semakin kecil nilai dari rasio tersebut maka semakin baik kinerja bank umum syariah dari segi FDR.

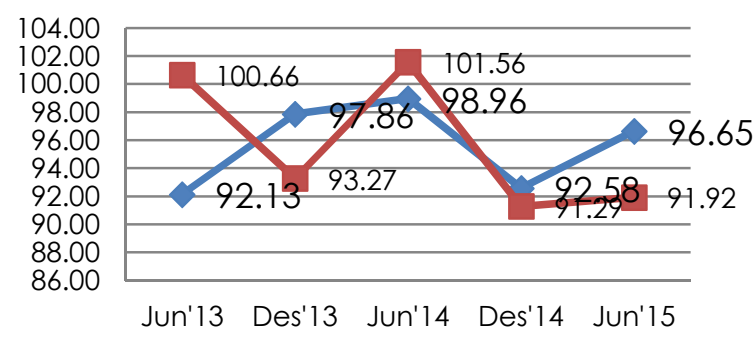

$\longrightarrow$ Spin Off - Akuisisi

Sumber: Diolah oleh Peneliti

Gambar 6

Perkembangan Mean Rasio FDR

Bank umum syariah hasil spin off mempunyai rasio BOPO yang lebih baik karena mempunyai nilai mean rasio BOPO per periode penelitian yang lebih kecil dibandingkan dengan bank umum 
Hisyam, et al/Jurnal Ekonomi Syariah Teori dan Terapan Vol. 3 No. 11 November 2016: 872-886; ANALISIS PERBANDINGAN KINERJA KEUANGAN BANK UMUM SYARIAH HASIL SPIN OFF DAN NON SPIN OFF PERIODE 2013-2015

syariah hasil akuisisi. Tidak terdapatnya perbedaan pada segi FDR untuk bank umum syariah hasil spin off dengan hasil akuisisi disebabkan oleh awal pendirian bank umum syariah tersebut. Adanya pembinaan dari induknya yaitu bank umum konvensional atas manjemen dalam penerimaan dan pengelolaan pembiaayan serta dana pihak ketiga untuk menjamin kinerja keuangan dilihat dari faktor likuiditas menjadikan tidak terdapat perbedaan pada kedua kategori bank umum syariah ini.

\section{SIMPULAN}

Berdasarkan uji beda $(a=0,05)$ pada periode 2013-2015 yang dilakukan dinyatakan bahwa

1. Pada faktor permodalan dengan rasio Capital Adequancy Ratio (CAR) tidak terdapat perbedaan kinerja kevangan antara bank umum syariah hasil spin off dan hasil akuisisi.

2. Pada faktor kualitas aset dengan rasio Non Performing Ratio (NPF) terdapat perbedaan kinerja kevangan antara bank umum syariah hasil spin off dan hasil akuisisi.

3. Pada faktor rentabilitas dengan rasio Return On Asset (ROA) terdapat perbedaan kinerja keuangan antara bank umum syariah hasil spin off dan hasil akuisisi.

4. Pada faktor rentabilitas dengan rasio Beban Operasional Pendapatan Operasional (BOPO) terdapat perbedaan kinerja keuangan antara bank umum syariah hasil spin off dan hasil akuisisi.
5. Pada faktor likuiditas dengan rasio Financing to Deposit Ratio (FDR) terdapat perbedaan kinerja keuangan antara bank umum syariah hasil spin off dan hasil akuisisi.

\section{DAFTAR PUSTAKA}

Anshori, Abdul Ghofur. 2010. Pembentukan Bank Syariah Melalui Akuisisi dan Konversi: Pendekatan Hukum Positif dan Hukum Islam. Yogyakarta: UII Press

Anshori, Muslich dan Sri Iswati. 2009. Buku Ajar Metodologi Penelitian Kualitatif. Surabaya: Pusat Penerbitan dan Percetakan Unair (AUP)

Arifin, Zainul. 2006. Dasar-dasar Manajemen Bank Syariah. Jakarta: Raja Grafindo Persada

Ashar, Asikin. 2010. Perbandingan Kinerja Kevangan Bank Muamalat Indonesia Sebelum dan Sesudah Krisis Ekonomi. Skripsi tidak diterbitkan. Surabaya. Universitas Airlangga.

Bank BCA Syariah. 2013-2015. Laporan Kevangan Triwulan 2 Bulan Juni. (online), (http://www.bcasyariah.co.id, diakses 2 Januari 2016)

2013-2015. Laporan Keuangan Triwulan 4 Bulan Desember. (online), (http://www.bcasyariah.co.id, diakses 2 Januari 2016)

$2014 . \quad$ Laporan Keuangan Tahunan. (online), (http://www.bcasyariah.co.id, diakses 2 Januari 2016)

Bank Indonesia. Peraturan Bank Indonesia. (online), (http://www.bi.go.id, diakses 7 September 2015) 
Hisyam, et al/Jurnal Ekonomi Syariah Teori dan Terapan Vol. 3 No. 11 November 2016: 872-886; ANALISIS PERBANDINGAN KINERJA KEUANGAN BANK UMUM SYARIAH HASIL SPIN OFF DAN NON SPIN OFF PERIODE 2013-2015

$\begin{array}{lr}\text { Indonesia. } & \text { Surat Edaran } \begin{array}{r}\text { Bank } \\ \text { (online), }\end{array} \\ \text { (http://www.bi.go.id, } & \text { diakses } 7 \\ \text { September 2015) } \\ \text { Bank BNI Syariah. 2013-2015. Laporan }\end{array}$

Keuangan Triwulan 2 Bulan Juni. (online), (http://www.bnisyariah.co.id, diakses 2 Januari 2016)

2013-2015. Laporan

Keuangan Triwulan 4 Bulan Desember. (online), (http://www.bnisyariah.co.id, diakses 2 Januari 2016)

$2014 . \quad$ Laporan

Keuangan Tahunan. (online),

(http://www.bnisyariah.co.id, diakses 2 Januari 2016)

Bank BRI Syariah. 2013-2015. Laporan Keuangan Triwulan 2 Bulan Juni. (online), (http://www.brisyariah.co.id, diakses 2 Januari 2016)

\section{3-2015. Laporan}

Keuangan Triwulan 4 Bulan Desember. (online), (http://www.brisyariah.co.id, diakses 2 Januari 2016)

$2014 . \quad$ Laporan

Keuangan Tahunan. (online),

(http://www.brisyariah.co.id, diakses 2 Januari 2016)

Bank Indonesia. Laporan Publikasi Bank Syariah. (online), (http://www.bi.go.id, diakses 9 September 2015)

Peraturan Bank Indonesia. (online), (http://www.bi.go.id, diakses 7 September 2015)

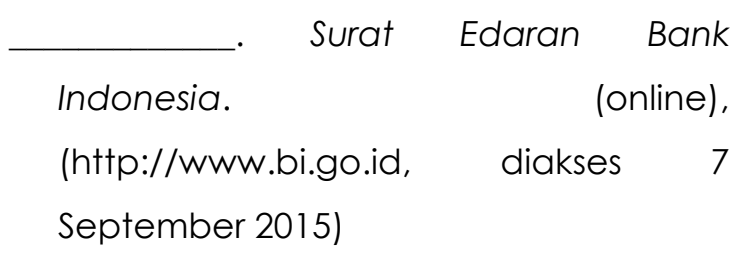

Bank Mega Syariah. 2013-2015. Laporan Kevangan Triwulan 2 Bulan Juni. (online),

(http://www.megasyariah.co.id,

diakses 2 Januari 2016)

2013-2015. Laporan

Kevangan Triwulan 4 Bulan Desember. (online),

(http://www. megasyariah.co.id, diakses 2 Januari 2016)

$2014 . \quad$ Laporan Kevangan Tahunan. (online), (http://www. megasyariah.co.id, diakses 2 Januari 2016)

Bank Panin Syariah. 2013-2015. Laporan Keuangan Triwulan 2 Bulan Juni. (online),

(http://www.paninsyariah.co.id, diakses 2 Januari 2016)

2013-2015. Laporan Keuangan Triwulan 4 Bulan Desember. (online), (http://www. paninsyariah.co.id, diakses 2 Januari 2016)

2014. Laporan Keuangan Tahunan. (online), (http://www. paninsyariah.co.id, diakses 2 Januari 2016)

Bank Syariah Bukopin. 2013-2015. Laporan Kevangan Triwulan 2 Bulan Juni. (online),

(http://www.syariahbukopin.co.id, diakses 2 Januari 2016)

2013-2015. Laporan

Keuangan Triwulan 4 Bulan Desember. (online), (http://www. syariahbukopin.co.id, diakses 2 Januari 2016) 
Hisyam, et al/Jurnal Ekonomi Syariah Teori dan Terapan Vol. 3 No. 11 November 2016: 872-886; ANALISIS PERBANDINGAN KINERJA KEUANGAN BANK UMUM SYARIAH HASIL SPIN OFF DAN NON SPIN OFF PERIODE 2013-2015

2014. Laporan

Keuangan Tahunan. (online),

(http://www. syariahbukopin.co.id,

diakses 2 Januari 2016)

Bank Syariah Mandiri. 2013-2015. Laporan

Keuangan Triwulan 2 Bulan Juni. (online),

(http://www.syariahmandiri.co.id,

diakses 2 Januari 2016)

2013-2015. Laporan

Keuangan Triwulan 4 Bulan Desember. (online),

(http://www.

syariahmandiri.co.id, diakses 2 Januari 2016)

2014. Laporan

Keuangan Tahunan. (online),

(http://www. syariahmandiri.co.id,

diakses 2 Januari 2016)

Dendawijaya, Lukman. 2003. Manajemen

Perbankan. Jakarta Selatan: Penerbit Ghalia Indonesia.

Departemen Agama RI. 2012. Al-Qur'an kU Arab, Latin dan Terjemahan. Jakarta: Lautan Lestari

Jumingan. 2006. Analisis Laporan Keuangan. Jakarta: PT.Bumi Aksara

Kasmir. 2013. Analisis Laporan Kevangan. Jakarta: Rajawali Pers.

Lestari dan Rahyuda. 2011. Analisis

Penilaian Tingkat Kesehatan Bank pada

Bank Muamalat Syariah Tbk Cabang

Denpasar. Jurnal Fakultas Ekonomi Universitas Udayana. (online). (http://www.elib.uud.ac.id, diakses tanggal 17 September 2015)

Lind, Douglas A, dkk. 2013. Teknik-teknik Statistika dalam Bisnis dan Ekonomi Menggunakan Kelompok Data Global
Edisi 13 Buku 1. Jakarta: Salemba Empat

Muhammad. 2005. Manajemen Dana Bank Syari'ah. Yogyakarta:Ekonisia Kampus Fakultas Ekonomi UII Yogyakarta.

Mulhadli. 2010. Hukum Perseroan dan Bentuk-Bentuk Badan Usaha di Indonesia. Bogor: Ghalia Indonesia

Quthb, Sayyid. 2000. Tafsir Fi Zhilail Qur'an Jilid 1. Jakarta: Gema Insani

Republik Indonesia. 2008. Undang-Undang Nomor 21 Tahun 2008 Tentang Perbankan Syariah. Jakarta: Republik Indonesia

1999. Peraturan

Pemerintah Republik Indonesia No.28 Tahun 1999 tentang Merger, Konsolidasi, dan Akuisisi Bank. Jakarta: Republik Indonesia

Santoso, Singgih. 2013. Menguasai SPSS di Era Informasi. Jakarta: Elex Media Komputindo

Solimun. 2002. Multivariate Analysis: Structural Equation Modelling (SEM), Lisrel dan Amos. Malang: Penerbit Universitas Negeri Malang

Sutojo, Siswanto. 1992. Manajemen Perusahaan Indonesia, Cetakan Pertama. Jakarta: Erlangga

Taswan. 2006. Manajemen Perbankan Konsep, Teknik dan Aplikasi. Yogyakarta: UPP STIM YKPN Yogyakarta. 